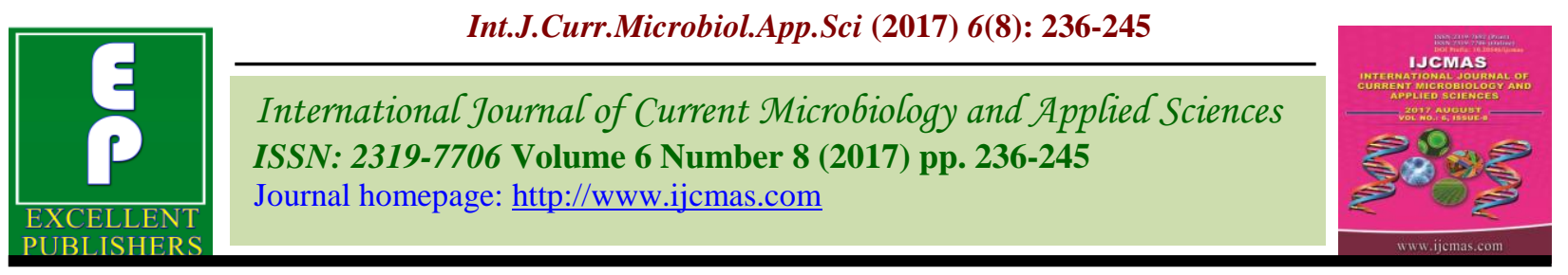

Review Article

https://doi.org/10.20546/ijcmas.2017.608.032

\title{
Review on Biochemical Changes Associated with Storage of Fruit Juice
}

\author{
Shailesh Kumar Singh ${ }^{1} *$ and Madhu Sharma ${ }^{2}$ \\ ${ }^{1}$ Department of Horticulture, School of Agriculture, Lovely Professional University, \\ Phagwara, Punjab, 144411, India \\ ${ }^{2}$ Department of Vegetable Science, Punjab Agricultural University, Punjab, 141004, India \\ *Corresponding author
}

\section{A B S T R A C T}

Keywords

Ascorbic acid,

Biochemical

change, Fruit

juice, Sugar, TSS.

Article Info

Accepted:

04 June 2017

Available Online:

10 August 2017
Intake of fresh vegetables and fruits has an inverse association risk for developing noncommunicable diseases primarily the coronary heart disease and nutritional disorders. It also reduces risk of obesity and to maintain a healthy body weight. High perishable nature of fruits and vegetables is detrimental in availability of these products for longer time so single strength or blended fruit juices can be alternative for nutritional security to human health. A wide range of biochemical changes occur during storage of juices at different temperature which reduces the nutritional value. However, proper understanding of these changes will help us to maintain the nutritional quality during processing and storage of fruit juice. The common biochemical changes studied are TSS (Total Soluble Solids), Ascorbic acid, titratable acidity, $\mathrm{pH}$, sugar, non-enzymatic browning and microbial growth.

\section{Introduction}

Intake of fruit and vegetables in human diet has significant role in reducing disease burden mortality in both developing and developed world. Low intake of these commodities had accounted for more than 2.6 million death throughout the world (Lock et al., 2005). Fruits and vegetables are good sources of vitamins, minerals, dietary fibre, phytochemicals (bioactive compounds) and antioxidants. High intake of these products provides protection against many noncommunicable diseases like cardiovascular disease (Lock et al., 2005), stroke (He et al., 2006), certain cancers (Gandini et al., 2000; WCRF, 2007), type-2 diabetes mellitus (Carter et al., 2010), the metabolic syndrome (Ford et al., 2003) and coronary diseases
(Abd-Ghafar et al., 2010). However, consumption of fresh fruits and vegetables is matter of availability in particular season as most of them are seasonal and are having very small shelf life. Thus, processed products of fruits and vegetables are of great significance which can be preserved for long duration with minimum loss in consumptive value. Among different processed products, fruit juices are gaining wider acceptability in dietary pattern throughout the world.

The fruit juice is very refreshing, delicious and soothing (Roger et al., 2002). Abeysinghe et al., (2007) had reported the presence of antioxidant, anti-inflammatory, anti-tumor, anti-fungal and blood clot inhibition activity 
and many bioactive compounds like ferrulic acid, hydrocinnamic acid, cyanidin glucoside, hisperidine, vitamin-C, carotenoid and naringin in citrus fruit juice ( $\mathrm{Xu}$ et al., 2008). However, processed juice suffers a wide range of biochemical changes during storage so required to be processed properly, preserved under appropriate conditions with suitable additives. Pasteurization, low temperature storage and concentrates making are promising methods of fruit preservation. Use of chemical preservatives, however, plays a very important role in ensuring safety and quality of stored foods. Preservatives are chemical agents intentionally added to food products to prevent or inhibit spoilage caused by moulds, yeasts and bacteria. The most common preservatives which are being used in fruit processing industries are salts releasing sulphur dioxide and salts of benzoic acid. Thus, biochemical changes taking place during preservation of fruit juice and their regulation to improve keeping quality has been reviewed in this manuscript (Figure 1).

\section{TSS variation in fruit juices during storage}

A gradual rise in TSS value during storage of fruit juice has been reported under all storage conditions which might be associated with continuous increase in hydrolysis of polysaccharides and acids. Bhardwaj (2013) proposed about the gradual passage of storage time as a function of increase in TSS which may be due to greater hydrolysis of polysaccharides. However, this rise in TSS is functional to storage temperature and a direct relation has been reported between increase in TSS and storage temperature. This might be correlated with lower rate of hydrolysis of sugars, poly-saccharides and organic acids at lower temperature following the La Chatelier Principles of chemical reactions. Prasad and and Mali (2000) had advocated about least increase in TSS under refrigerator storage of Kinnow juice due to reduced hydrolysis of polysaccharides and acids. Bahardwaj and Nandal (2014) had also proposed similar finding to show that TSS of blended Kinnow juice is directly correlated with storage duration and increase in TSS is higher at ambient condition due to high rate of solubilization or hydrolysis of acid into sugars. Similar, finding have been confirmed by Deka and Sethi (2001) in mixed fruit juice spiced beverage, Singh and Mathur (1983) in cashew apple juice and Bhardwaj and Mukherjee (2011) in Kinnow juice.

\section{Ascorbic acid variation in fruit juices during storage}

Ascorbic acid degradation is common in all consumable items during storage and can occur aerobically as well as anaerobically. However rate of aerobic degradation is 100 to 1000 times faster than anaerobic degradation. Vitamin $C$ is light and heat sensitive, the concentration of Vitamin $\mathrm{C}$ follows first order kinetics and thus storage time affects Vitamin C content (Heldman and Singh, 1981). Blasco et al., (2004) had also reported two different degradation pathways of vitamin $\mathrm{C}$ during storage. Aerobic degradation was observed in the beginning due to presence of oxygen in the bottle but after prolonged heating the bottle becomes saturated with vapor and becomes oxygen deficient which induced anaerobic degradation. Carvalho et al., (2007) reported a decreasing trend in vitamin $\mathrm{C}$ content in cashew apple juice blended with coconut water during storage. Similar trend was also reported in cashew apple juice by Maia et al., (2001) and Costa et al., (2003). Kabasakalis et al., (2000) had found $29-41 \%$ of ascorbic acid loss after 4 months when fruit juices were stored at room temperature while Burdulu et al., (2006) found $27.3-45.3 \%$ loss in ascorbic acid when orange juice was stored at $28^{0} \mathrm{Cfor} 2$ months and was in line to findings of Burdulu et al., (2006). Majumdar et al., (2009) reported 74\% loss in ascorbic 
acid in cucumber + litchi + lemon blended juice stored for 6 months.

The stability of ascorbic acid in consumable items is also affected by temperature, $\mathrm{pH}$, sunlight and the presence of metals like copper and iron (Bhargawa et al., 2014). Thus, storage condition has greater influence over ascorbic acid retention in food components. In presence of light and temperature ascorbic acid is oxidized to dehydroascorbic acid so causing significant loss in beverages and nectars (Ahmed et al., 2008; Kalra and Tondon, 1984). Ahmed et al., (2008) studied storage quality of citrus juice and reported that ascorbic acid contents decreased significantly at all storage intervals which depends on the processing methods, storage duration and light exposure.

Storage temperature is one of the measure contributing factors for ascorbic acid degradation during storage as it is highly thermal sensitive. Pasteurization of fruit juice produces $\mathrm{p}$-vinylguaiacol (PVG) and induces ascorbic acid degradation (Naim et al., 1997). Lotha et al., (1994) reported that Kinnow mandarin fruit stored at ambient temperature $\left(9^{0} \mathrm{C}-24^{0} \mathrm{C}\right.$; $\left.\mathrm{RH} 65-90 \%\right)$ have life of 22 days and the amount of ascorbic acid was reported to decrease where the fruit was stored at refrigerated temperature $\left(3^{0} \mathrm{C}\right.$; $\left.\mathrm{RH} 70-80 \%\right)$ with a shelf life of 60 days. Cvetković and Jokanović (2009) reported that after 30 days of storage at $4-8^{0} \mathrm{C}$ overall loss in ascorbic acid was from $81.01 \%$ to $90.27 \%$ in thermally pasteurized samples. According to Vikram et al., (2005), the degradation was rapid at higher temperatures. The ascorbic acid degradation rate in the orange-carrot juice stored at $2^{\circ} \mathrm{C}$ was less than in the juice stored at $10^{\circ} \mathrm{C}$, and in the pasteurized juice it was greater (Torregrosa et al., 2006).

Application of materials with anti-oxidant properties or antimicrobial properties has potential to improve retention of ascorbic acid during storage of fruit juice. Sulphur dioxide acts as good antioxidant for ascorbic acid so $\mathrm{SO}_{2}$ fumigation or using sulfites, metabisulphites of sodium or potassium reduces oxidation and microbial degradation of ascorbic acid. El-Ashwah et al., (1981) stated that sulfites and meta-bi-sulphite of sodium or potassium can be added to fruit juices as potential sources of sulfur dioxide to stabilize ascorbic acid. The application of KMS (potassium meta-bi-sulphite) to reduce the loss of ascorbic acid during the storage of leafy vegetables has also been reported by Negi and Roy (2000). Mathooko and Kiniiya (2002) proved that sodium metabisulfite had significant effect on stabilizing the ascorbic acid and it concentration of had directly influenced the ascorbic acid retention. Zheng and Wang (2001) had also reported upto eighty percent loss in ascorbic acid content in Kinnow nectar however, significant retention in ascorbic acid was reported in aloe juice blended Kinnow nectar confirming positive impact of phenolic components present in aloe juice. Jain and Khurdiya (2009) in aonla juice study confirmed that pasteurization action at low temperature, use of sulphites and low temperature storage improved ascorbic acid retention.

\section{Acidity variation in fruit juices during storage}

The titratable acidity of fruits or fruit juice includes the organic acids predominantly present in fruits (Table 1). These organic acids are of high nutritional values and are useful in extending shelf life of fruit juice during storage. However, these are highly sensitive to temperature, storage condition and duration. The organic acids undergo degradation during storage which might be due to conversion of acids into sugar and salt by invertase enzymes as suggested by Jain et al., (1986). Singh et al., (2005) advocated that 
titrable acid content in bael beverage was significantly decreased during 6 months storage, which is in conformity with Singh et al., (2009) for 74 days storage of Kinnow juice. Bhardwaj and Nandal (2014) had reported decrease in acidity of stored Kinnow juice due to oxidation as the period of storage advanced but the decrease was lower under refrigerated storage condition due to enzymatic inactivation. These findings are in conformity with Sethi et al., (1980) in long duration Kinnow juice storage at ambient and refrigerated condition. Pareek et al., (2011, 2015) had also reported declining trend of acid loss in mandarin juice during 180 days of storage which was found to be declined at low temperature and high humidity due to reduced conversion of acids in to sugar and salt by invertase enzymes. They had further advocated the minimum loss of acidity during storage when treated with KMS and the loss was found to be reduced as the concentration of KMS increased.

\section{$\mathrm{pH}$ variation in fruit juices during storage}

The $\mathrm{pH}$ of fruit juice is negative function of natural acidity in the juice, thus increase in $\mathrm{pH}$ is accompanied with decrease in acidity of fruit juice during storage (Rehman et al., 2014). Rehman et al., (2014) described that the possible reason for increase in $\mathrm{pH}$ with prolonged storage of Kinnow juice may be the acid hydrolysis of the poly-saccharides into mono-saccharides and di-saccharides which are responsible for increase in sweetness and decrease in sourness (Dhaka et al., 2016). The results of present investigation are in line with the findings of Alaka et al. (2003). The acidity of juice is also influenced by preservatives added and storage condition. Nwachukwu and Ezeigbo (2013) revealed a synergism between pasteurization; acidification and sodium benzoate treatment and reported an increase in $\mathrm{pH}$ of soursop juice and decrease in acidity which was more in pasteurized juice in comparison to low value in sodium benzoate treated juice.

\section{Sugar variation in fruit juices during storage}

The fruit juice contains various reducing and non-reducing sugars which tend to change during storage due to various interconversion processes. The increase in total sugars could be result of hydrolysis of polysaccharides like pectin, cellulose and starch into simple sugars as reported by Singh and Mathur (1983) in cashew apple juice. They had proposed that an increase in reducing sugar during storage may be due to gradual conversion of nonreducing sugar and acids into reducing sugars. Ahmed et al., (2008) reported that a significant increase in reducing sugar during storage of citrus juice which may be due to acid hydrolysis of sucrose (non-reducing sugar) to glucose and fructose. Similar observations were also reported by Babsky et al., (1986), and Pruthi et al., (1984). However, these decline in non-reducing sugar was slow and non-significant at initial phase of storage while significant at later stage. A similar decline in non-reducing sugar was observed by Sandi et al., (2004), during storage of fruit drinks.

The accumulation of reducing sugars has been reported to be more in sulphur dioxide or KMS preserved fruit juice which could be attributed to acid induced hydrolysis of polysaccharides and disaccharides into monosaccharides (reducing sugar) due to formation of sulphurous acid (Pareek et al., 2015). Similarly, Garg et at., (2008) had also reported increase in reducing and total sugar content during storage in blended Indian gooseberry juice treated with $0.05 \%$ KMS. Amin et al., (2008) had also observed pronounced similar effect of chemical preservatives like potassium meta-bi-sulphite (KMS), citric acid and sodium benzoate (SB) 
on sugar content of mango pulp. Shahnawaz et al., (2015) reported a non-significant but higher total sugar and reducing sugar in orange juice treated with sodium-benzoate $(1.0 \mathrm{~g} / 1000 \mathrm{ml})$. The rising temperature during storage also accelerates hydrolysis of acids and poly-saccharides into simple sugars (Bhardwaj and Nandal, 2014). Sarmah et al., (1981) observed considerable increase in reducing sugar content in single strength Kinnow mandarin juice in the samples at room temperature as compared to those kept at low temperature.

\section{Browning of fruit juice during storage}

Browning of fruit juice during storage is result of a non-enzymatic chemical reaction between amino acids and reducing sugars called as Maillard reaction. HMF (hydroxymethylfurfural), formed in the Maillard reaction as well as during caramelization (pyrolysis of sugar), is the main product during storage which cause browning of food (Arribas-Lorenzo and Morales, 2010).

Table.1 Sources and importance of various organic acids

\begin{tabular}{|c|c|c|c|}
\hline S.No. & $\begin{array}{l}\text { Organic } \\
\text { Acid }\end{array}$ & Fruits & Importance \\
\hline $\mathbf{1}$ & $\begin{array}{l}\text { Citric } \\
\text { Acid }\end{array}$ & $\begin{array}{l}\text { Citrus fruits, tomato, berries, pineapple, pear, } \\
\text { cherries and lettuce }\end{array}$ & $\begin{array}{l}\text { Inhibits formation of stones in kidney } \\
\text { and stimulates the breakdown of } \\
\text { smaller kidney stones. }\end{array}$ \\
\hline 2 & $\begin{array}{l}\text { Malic } \\
\text { Acid }\end{array}$ & $\begin{array}{l}\text { Apple, pear, water melon, apricots, bananas, } \\
\text { blackberries, cherries, grapes, kiwi, lychees, } \\
\text { mango, nectarines, oranges, peaches, pears and } \\
\text { strawberries, tomato, broccoli and rhubarb }\end{array}$ & $\begin{array}{l}\text { It is used in fibromyalgia and chronic } \\
\text { fatigue syndrome. It is also used to } \\
\text { reduce muscle soreness and increase } \\
\text { energy levels. }\end{array}$ \\
\hline 3 & $\begin{array}{l}\text { Oxalic } \\
\text { Acid }\end{array}$ & Leafy green vegetables, rhubarb and beets & $\begin{array}{l}\text { Excess use of oxalic acid has potential } \\
\text { risk of stone formation, however } \\
\text { limited use can prevent further } \\
\text { development of kidney stones. }\end{array}$ \\
\hline 4 & $\begin{array}{l}\text { Tartaric } \\
\text { Acid }\end{array}$ & $\begin{array}{l}\text { Grapes, banana, tamarind, apricots, apples and } \\
\text { avocados }\end{array}$ & $\begin{array}{l}\text { It is used as an additive and flavoring } \\
\text { agent in food industries. }\end{array}$ \\
\hline
\end{tabular}

Fig.1 Common trend of change in biochemical parameters of fruit juice during storage

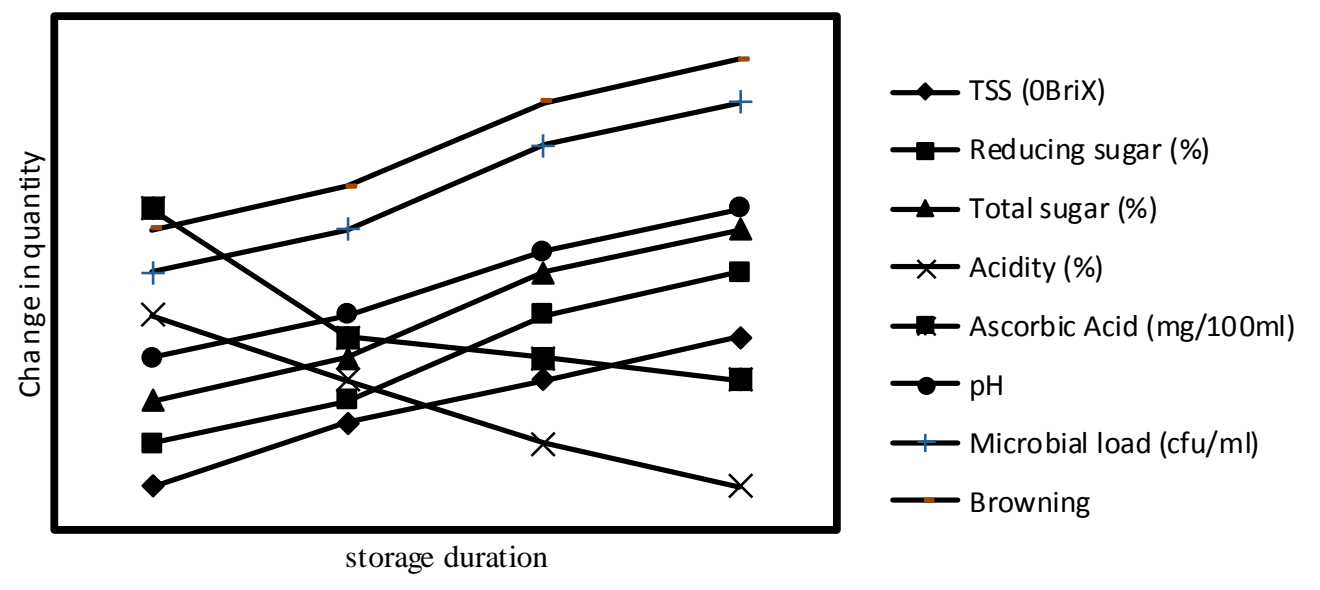


The formation of HMF is accelerated by storage time and temperature (Serra-Cayuela et al., 2014). However, Nie et al., (2013) had proposed temperature dependent three sugaramino acid (glycine) models for Maillard reaction and reported that the mechanism is completely temperature dependent and attributed to selective sugar types, $\mathrm{pH}$, temperature, and heating time. Saini et al., (2000) observed that the browning in mango pulp upto $83.33 \%$ can be reduced by the application of potassium meta-bi-sulphite. Bhardwaj (2013) had reported a liner increase in non-enzymatic browning during storage of blended juice of Kinnow for 6 month. Bhardwaj and Nandal (2014) reported that low temperature lead to a decline in the enzymatic and non-enzymatic browning reaction in blended Kinnow juice in presence of KMS.

\section{Microbial contamination of fruit juice during storage}

Microbial contamination is an important aspect of food safety and standards and is measured in colonies forming units per unit of volume. Rahman et al., (2011) had reported that the desirable fungal count in all products should be in order of $10^{3}-10^{5}(\mathrm{cfu} / \mathrm{ml})$. The microbial contamination can occur at any step from production to consumption but the microbial growth during storage depends on quality of packaging, storage temperature and preservatives added. Hashmi et al., (2007) reported that the mango pulp stored at ambient temperature $\left(30^{\circ} \mathrm{C}-36^{\circ} \mathrm{C}\right)$ with $0.2 \%$ KMS showed negligible microbial growth. Chauhan et al., (2002) reported that microbiological population (total plate counts, and yeast and mold counts) increased during storage of sugarcane juice at room temperature in comparison to storage at refrigeration temperature. Nwachukwu and Ezeigbo (2013) had also reported lower microbial load in sodium benzoate treated and pasteurized soursop juice, while Ogiehor et al., (2004) and Akhtar et al., (2009) reported lower microbial growth due to KMS treatment. Amin et al., (2008) showed reduced microbial growth in during storage of fruit juice by using Potasium sorbate, Sodium Benzate and KMS, while Deka and Sethi (2001) reported inhibitory effect of spices (ginger juice) towards microbial growth. Yigeremu et al., (2001) and Mutaku et al., (2005) concluded that preservatives significantly reduced the microbial growth in comparison to untreated papaya juice.

\section{References}

Abd-Ghafar, M.F., Prasad, K.N., Weng, K.K., and Ismail, A. 2010. Flavonoid, hesperidine, total phenolic contents and antioxidant activities from Citrus species. Afr. J. Biotechnol., 9: 326-330.

Abeysinghe, D. C., Li, X., Sun, C. D., Zhang, W. S., Zhou, C. H., and Chen, K. S. 2007. Bioactive compounds and antioxidant capacities in different edible tissues of citrus fruit of four species. Food Chem., 104: 1338-1344.

Ahmed, M., Ahmad, A., Chatha, Z. A., and Dilshad, S.M.R. 2008. Studies on preparation of ready to serve mandarin (Citrus reticulata) diet drink. Pak. J. Agric. Sci., 45(4): 470-476.

Akhtar, S., Mahmood, S., Naz, S., Nasir, M., and Sultan, M. T. 2009. Sensory evaluation of mangoes (Mangifera indica.L) grown in different regions of Pakistan. Pak. J. Bot., 41(6): 28212829.

Alaka, O. O., Aina, J. O., and Falade, K. O. 2003. Effect of storage conditions on the chemical attributes of ogbomoso mango juice. Food Res. Tech., 37: 213217.

Amin, M., Aman, U. M., Mazhar, M. S., Islam, U. D., Khalid, M. S., and Saeed, A. 2008. Mango fruit desapping in 
relation to time of harvesting. Pak. $J$. Bot., 40(4): 15871593.

Arribas-Lorenzo, G., and Morales, F. J. 2010. Estimation of dietary intake of 5hydroxymethylfurfural and related substances from coffee to Spanish population. Food Chem. Toxicol., 48(2): 644-649.

DOI:10.1016/j.fct.2009.11.046.

Babsky, J. E., Toribio, J. L., and Lozano, J. E. 1986. Influence of storage on the composition of clarified apple juice concentrate. J. Food Sci., 51(3): 564567.

Bhardwaj, R. L. 2013. Physico-chemical, sensory and microbiological quality of Kinnow juice stored in refrigerated storage condition. Asian J. Dairy Food Res., 32: 203-213.

Bhardwaj, R. L., and Mukherjee, S. 2011. Effects of fruit juice blending ratios on Kinnow juice preservation at ambient storage condition. Afr. J. Food Sci., 5: 281-286.

Bhardwaj, R. L., and Nandal, U. 2014. Effect of storage temperature on physicochemical and sensory evaluation of Kinnow mandarin juice blends. J. Food Process. Technol., 5(8).

Bhargawa, S., Kapoor, S., Ranote, P. S., and Sharma, S. 2014. Studies on Aloe Juice Supplemented Kinnow Nectar. Res. J. Agriculture and Forestry Sci., 2: 14-20.

Blasco, R., Esteve, M. J., Frigola, A., and Rodrigo, M. 2004. Ascorbic acid degradation kinetics in mushrooms in a high-temperature short time process controlled by a thermoresistometer. Lebensm.-Wiss. u.-Technol. 37: 171175.

Burdulu, H. S., Koca, N., and Karadeniz, F. 2006. Degration of vitamin C in citrus juices concentrates during storage. $J$. Food Eng., 74: 211-216.

Carter, P., Gray, L. J., Troughton, J., Khunti, K., and Davies, M. J. 2010. Fruit and vegetable intake and incidence of type-2 diabetes mellitus: systematic review and meta-analysis. British Med. J., 341: c4229. DOI:10.1136/bmj.c4229

Carvalho, J. M. D., Maia, G. A., Figueiredo, R. W., Brito, E. S. D., and Rodrigues, S. 2007. Storage stability of a stimulant coconut water-cashew apple juice beverage. J. Food Proce. \& Prese., 31:178-189.

Chauhan, O. P., Singh, D., Tyagi, S. M., and Balyan, D. K. 2002. Studies on preservationof sugarcane juice. Int. $J$. Food Prop., 5(1): 217-229.

Costa, M. C. O., Maia, G. A., Figuiredo, R. W., Souza Filho, M. S. M., and Brasil, I. M. 2003. Storage stability of cashew apple juice by hot fill and asseptic processes. Cienc. Tecnol. Alimen., 23: 106-109.

Cvetković, B. R., and Jokanović, M. R. 2009. Effect of preservation method and storage condition on ascorbic acid loss in beverages. BIBLID: 1450-7188, 40: $1-7$.

Deka, B. C., and Sethi, V. 2001. Preparation of mixed fruit juice spiced RTS beverages. Ind. Fd. Packer., 42(3): 5861.

Dhaka, A., Sharma, M., and Singh, S.K. 2016. Use of Additives to Reduce Browning, Microbial Load and Quality Loss of Kinnow Juice under Ambient Storage. Indian J. Sci. Technol., 9(14). DOI: 10.17485/ijst/2016/v9i14/80907

El-Ashwah, E. T., Tawfik, M. A., ElHashimy, F. S., Rouf, M. S., and Sarhan, M. A. 1981. Chemical and Physical Studies on Preserved 'Benzahir' Lime Juice. Sudan J. Food. Sci. Technol., 13: 64-68.

Ford, E. S., Mokdad, A. H., Giles, W. H., and Brown, D. W. 2003. The metabolic syndrome and antioxidant concentrations. Findings from the third national health and nutrition 
examination survey. Diabetes, 52: 2346-2352.

Gandini, S., Merzenich, H., Robertson, C., and Boyle, P. 2000. Meta-analysis of studies on breast cancer risk and diet: the role of fruit and vegetable consumption and the intake of associated micronutrients. Eur. J. Cancer, 36: 636-646.

Garg, V., Barwal, V. S., and Sarera, S. 2008. Preparation and evaluation of vitamin $\mathrm{C}$ enriched fruit drink. J. Food Sci. Technol., 45: 524-526.

Hashmi, M. S., Alam, S., Riaz, A., and Shah, A. S. 2007. Studies on Microbial and Sensory Quality of Mango Pulp Storage with Chemical Preservatives. Pak. J. Nutri., 6(1): 85-88.

He, F. J., Nowson, C. A., and MacGregor, G. A. 2006. Fruit and vegetable consumption and stroke: meta-analysis of cohort studies. Lancet, 367: 320-326.

Heldman, D. R., and Singh, R. P. 1981. Food Process Engineering. AVI Publishing Co., New York.

Jain, S. K., and Khurdiya, D. S. 2009. Ascorbic acid content and nonenzymatic browning in stored Indian gooseberry juice as affected by sulphitation and storage. J. Food Sci. Technol., 46: 500-501.

Jain, S. P., Tripathi, V. K., Ram, H. B., and Singh, S. 1986. Effect of storage conditions on storage life of some important squashes. Ind. Food Pack, 2: 36-41.

Kabasakalis, V., Siopidou, D., and Moshatou, E. 2000. Ascorbic acid content of commercial fruit juices and its rate of loss upon storage. Food Chem., 70: 325-328.

Kalra, S. K., and Tandon, D. K. 1984. Guava nectars from sulphited pulp and their blends with mango nectar. Ind. Food Pack, 38: 74-77.

Lock, K., Pomerleau, J., Causer, L., Altman,
D. R., and McKee, M. 2005. The global burden of disease attributable to low consumption of fruit and vegetables: implications for the global strategy on diet. Bull. World Health Organization, 83(2): 100-108.

Lotha, R. E., Khurdiya, D. S., and Mahashwari, M. L. 1994. Effect of storage of on the quality of Kinnow mandarin for juice processing. Ind. Food Pack, 25-37.

Maia, G. A., Monteiro, J. C. S., and Guimaraes, A. C. I. 2001. Estudo da estabilidade físico-química do suco de caju com alto teor de polpa. Cienc. Tecnol. Alimen., 21: 43-46.

Majumdar, T. K., Vasudish, C. R., Premavalli, K. S., and Bawa, A. S. 2009. Development and storage stability of cucumber-litchi-lemon Juice. J. Food Sci. Technol., 46: 269-270

Mathooko, F. M., and Kiniiya, E. N. 2002. Ascorbic acid retention in canned lime juice preserved with sulfur acid dioxide and benzoic. Afric. J. Food Agr. Nutri. Dev., 2(1): 33-37.

Mutaku, I., Erku, W., and Ashenafi, M. 2005. Growth and survival of Escherichia coli O157: H7 in fresh tropical fruit juices at ambient and cold temperatures. Int. $J$. Food Sci. Nutr., 56: 133-139.

Naim, M., Schutz, O., Zehavi, U., Rouseff, R. L., and Haleva, T. E. 1997. Effects of orange juice fortification with thiols on p-vinylguaiacol formation, ascorbicacid degradation, browning, and acceptance during pasteurization and storage under moderate conditions. $J$. Agric. Food Chem., 45(5): 1861-1867.

Negi, P. S., and Roy, K. 2000. Effect of blanching and drying method on carotene, ascorbic acid and chlorophyll retention of leafy vegetable. $L W T$ - Food Sci. Technol., 33: 295-298.

Nie, S., Huang, J., Hu, J., Zhang, Y., Wang, S., Li, C., and Xie, M. 2013. Effect of 
$\mathrm{pH}$, temperature and heating time on the formation of furan in sugar-glycine model systems. Food Sci. Human Wellness, 2(2): 87-92.

Nwachukwu, E., and Ezeigbo, C. G. 2013. Changes in the microbial population of pasteurized soursop juice treated with benzoate and lime during storage. African J. Microbiol. Res., 7: 39923995.

Ogiehor, S. I., and Ikenebomehclearly, M. J. 2004. Antimicrobial effects of sodium benzoate on the growth, survival and aflatoxin production potential of some species of Aspergillus in Garri during storage. Pak. J. Nutr., 3: 300-330.

Pareek, S., Paliwal, R., and Mukherjee, S. 2011. Effect of juice extraction methods and processing temperature-time on juice quality of Nagpur mandarin (Citrus reticulata Blanco) during storage. J. Food Sci. Technol., 48:197203.

Pareek, S., Paliwal, R., and Mukherjee, S. 2015. Effect of juice extraction methods, potassium meta-bi-sulphite concentration and storage temperature on the extent of degradation and reactivity of chemical constituents in mandarin (Citrus reticulata Blanco) juice. J. Food Agric. Environ., 13: 3944.

Prasad, R. N., and Mali, P. C. 2000. Change in physico -chemical characteristics of pomegranate squash during storage. Indian J. Hort., 57: 18-20.

Pruthi, J. S., Manan, J. K., Teotia, M. S., Podhakri-Shnasetty, G., Epison, W. E., Saroja, S., and Chikkappaji, K. C. 1984. Studies on the utilization of Kinnow and Malta. J. Food Sci. Technol., 21(3): 123-127.

Rahman, T., Hasan, S., and Noor, R. 2011. An assessment of microbiological quality of some commercially packed and fresh fruit juices available in Dhaka city: a comprehensive study. Stanford J. Microbiol., 1(1): 13- 18.

Rehman, M. A., Khan, M. R., Sharif, M. K., Ahmad, S., and Shah, F. H. 2014. Study on the storage stability of fruit juice concentrates. Pak. J. Food Sci., 24: 101107.

Roger, G. D. P. 2002. Education and health. Liberary editorial safeliz S.L Spain. 153-154.

Saini, S., Sogi, D. S., and Bawa, A. S. 2000. Shelf-life studies on chemically preserved sand pear (Pyrus pyrifolia cv. patharnakh) pulp. Mysore- J. Food Sci. Tech., 40: 230-232.

Sandi, D., Jose, B. P., Antonio, C. G., June, F. M., Marco, T. C., and Patricia, B. L. 2004. Hunter color dimensions, sugar contents and volatile compounds in Pasteurized yellow passion fruit juice during storage. Braz. Arch. Biol. Technol., 47(2): 233-245.

Sarmah, U., Bains, G. S., and Kripal, S. K. 1981. Studies on the processing of Kinnow mandarin juice. Punjab Hort. J., 21: 32-45.

Serra-Cayuela, A., Jourdes, M., RiuAumatell, M., Buxaderas, S., Teissedre, P. L., and López-Tamames, E. 2014. Kinetics of browning, phenolics, and 5hydroxymethylfurfural in commercial sparkling wines. J. Agr. Food Chem., 62(5): 1159-1166.

Sethi, V., Anand, J. C., and Saxena, S. K. 1980. Kinnow orange in juice and beverage making, Indian Hort., 25(3): 13.

Shahnawaz, M., Sheikh, A. S., and Minhas, S. 2015. Role of sodium benzoate as a chemical preservative in extending the shelf life of orange juice. Glo. Adv. Res J. Food Sci. Technol., 2: 007-018.

Singh, K., and Mathur, P. B. 1983. Studies in the cold storage of cashew apple. Indian J. Hort., 40: 115-121.

Singh, S. V., Jain, R. K., Gupta, A. K. 2009. 
Changes in quality of debittered Kinnow juice during storage. J. Food Sci. Technol., 46: 598-600.

Singh, S., Godara, R. K., Saini, R. S., and Sharma, J. R. 2005. Standardization of processing technology for bael/blended bael (Aegle marmelos) ready-to-serve beverages. Haryana J. Hort. Sci., 34: 263- 265.

Torregrosa, F., Esteve, M. J., Frígola, A., and Cortés, C. 2006. Ascorbic acid stability during refrigerated storage of orangecarrot juice treated by high pulsed electric field and comparison with pasteurized juice. J. Food Eng., 73(4): 339-345.

Vikram, V. B., Ramesh, M. N., and Prapulla, S. G. 2005. Thermal degradation kinetics of nutrients in orange juice by electromagnetic and conventional methods. J. Food Eng., 69: 31-40.
WCRF. 2007. World Cancer Research Fund / American Institute for Cancer Research. Food, Nutrition, Physical Activity, and the prevention of cancer: a global perspective. AIR, Washington DC, Chapter 4.

Xu, G., Liu, D., Chen, J., Ye, X., Ma, Y., and Shi, J. S. 2008. Juice components and antioxidant capacity of citrus varieties cultivated in China. Food Chem., 106: 545-551.

Yigeremu, B., Bogale, M., and Ashenafi, M. 2001. Fate of Salmonella species and E. coli in fresh-prepared orange, avocado, papaya, and pineapple juices. Ethiop. J. Health Sci. 11: 89-95.

Zheng, W., and Wang, S. Y. 2001. Antioxidant activity and phenolic compounds in selected herbs. J. Agric. Food Chem., 49(11): 5165-5170.

\section{How to cite this article:}

Shailesh Kumar Singh, Madhu Sharma. 2017. Review on Biochemical Changes Associated with Storage of Fruit Juice. Int.J.Curr.Microbiol.App.Sci. 6(8): 236-245.

doi: https://doi.org/10.20546/ijcmas.2017.608.032 